Egyptian Veterinary Medical Society

of Parasitology Journal

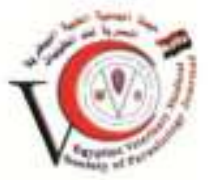

\title{
Original Article \\ Prevalence of Mites in Some Clinically Infected Animals in Behera Province
}

\author{
Haggag Y.N. ${ }^{1}$, \\ Mohammad A. \\ Nossair ${ }^{1}$, Heba M. \\ Habib ${ }^{1}$, Abd El Rasoul \\ M. Mohammad ${ }^{1}$ and \\ Mousa A. Ayoub ${ }^{2}$ \\ ${ }^{1}$ Animal Hygiene and \\ Zoonoses Department, \\ Faculty of Veterinary \\ Medicine, Alexandria \\ University, \\ ${ }^{2}$ Animal Hygiene and \\ Zoonoses Department, \\ Faculty of Veterinary \\ Medicine, Damanhur \\ University
}

\begin{abstract}
:
The current work was undertaken to determine the role of some animal species in transmitting mites to their human contact. A total of 100 hair and skin scrapings were collected from clinically suspected mange like lesions found on different parts of the body of individually owned animals from Abo El Matameer District, Behera Province during the period extended from June 2014 to May 2015. Samples included cattle, buffaloes, sheep and horses (25 samples of each) of different ages and sex. Results revealed that the highest prevalence was observed in sheep (72\%) followed by cattle $(48 \%)$ then buffaloes (36\%) and finally horses (28\%). Statistical analysis showed non-significant association between the prevalence of mites and sex of investigated animals while there was a significant association between the prevalence of mites and different age groups that older animals were more susceptible to infection than young animals. Microscopic identification clarified that that the overall prevalence of Sarcoptes spp. and Psoroptes spp. was 56.52 and $43.48 \%$, respectively. Finally, it was clear that cattle, buffaloes, sheep and horses could be considered potential reservoirs for scabies.
\end{abstract}

Key words: Mites, Farm Animals, Equines, Prevalence

\section{INTRODUCTION}

Skin infections are a common public health problem in developing countries; however, they are rarely managed using a population based approach. Skin affections due to zoonotic pathogens constitute a major public health hazard including scabiosis. Scabies remains the most prevalent, endemic, and neglected ectoparasitic infection globally and can cause recurrent outbreaks. Although its distribution is subjected to a cycle of infection, with peaks and troughs of disease prevalence, this periodicity is often less obvious in poor communities. Several epidemiological factors have been proposed as influencing the distribution of scabies infection in populations, including: age, gender, ethnicity, overcrowding, hygiene, and season (Burkhart et al., 2000).

The cosmopolitan mite Sarcoptes scabiei (Acari: Sarcoptidae) is an obligatory ectoparasite that infects the skin of a wide range of mammalian hosts resulting in sarcoptic mange in companion animals, livestock, and wildlife, as well as scabies in humans (Pence and Ueckermann, 2002). The 
disease is highly contagious, characterized by pruritic dermatitis, alopecia, hyperkeratosis, and crust formation and if left untreated, can lead to death due to dehydration, pneumonia, or bacterial septicemia (Nimmervoll et al., 2013). In addition to its potential to cause huge economic losses due to weight loss and mortality in animals, scabies imposes a global public health concerns as an emerging/re-emerging infectious disease (Alasaad et al., 2013).

Sarcoptes scabiei var bovis is a highly contagious disease spread by direct contact between infected and susceptable animals or by contaminated fomites. Lesions caused by these burrowing mites start on the head, neck, and shoulders and can spread to other parts of the body. The whole body may be involved in 6 weeks. Pruritus is intense, and papules develop into crusts; skin thickens and forms large folds while psoroptic mange in cattle and sheep is caused by infection with Psoroptes ovis which is a non-burrowing mite that lives on the skin surface. All stages of the mite are found on the host, and transmission is through direct contact of infected and susceptible hosts (Blood et al., 1990).

Sarcoptes scabiei var equi is rare but is the most severe type of mange in horses. Infected horses suffered severe itching and sometimes biting of affected skin areas and decrease feed consumption. The skin lesions mainly start as erythematous area followed by developing of papules and crust formation. Skin scratches as a result of traumatized lesions usually occurred and hair was lost on the affected parts developing irregular alopecic areas (Osman et al., 2006).

Many studies have investigated the occurrence of scabiosis in farm animals (Warnick et al. 2002, Biu and Wakawa 2004, Kollbrunner et al. 2010, Millar et al. 2011, Mitchell et al. 2012, Sarre et al. 2012, Fuller 2013 and Salifou et al. 2013). While in Egypt, scabies has been reported in farm animals and humans by Kenawi et al., (1993), Osman et al. (2006), ElKhodery et al. (2009), Nofal, (2009), Yassin (2011) and Amer et al. (2015).

Scabies spread by a mite Sarcoptes scabiei var hominis. The itch and rash appeared to be largely the result of a delayed (type IV) allergic reaction to the mite, its eggs and excreta. Scabies was spread by skin to skin contact between healthy and infected person, but occasionally via contaminated bed linen, clothes or towels. The pathognomonic sign of scabies include areas of dry, scaly, hyperkeratotic and crusted skin, particularly on the extremities (Tidman and Tidman, 2013).

So, the aims of the current study are determination of the prevalence of zoonotic mites among farm animals and throwing the light upon the public health significance of scabies and establish suggestive control measures in order to minimize the public health hazards.

\section{MATERIAL AND METHODS}

\section{1- Specimens collection:}

A total 100 animals clinically showing pruritus with papules or crusts, thickened skin and large folds were selected from individually owned 
animals from different farms and veterinary clinics including; cattle, buffaloes, sheep and horses (25 for each) of different ages and sex. A scalpel blade is used for the deep scrapings (until blood oozes) needed to demonstrate parasites that live in burrows or hair follicles. Samples were transported with the minimum of delay to the laboratory of Animal Health Research Institute, Alexandria where they were subjected to direct microscopic examination for presence of mites.

\section{RESULTS AND DISCUSSION}

Table (1): Distribution of animal samples under different factors of investigation

\begin{tabular}{|l|c|c|c|c|}
\hline \multirow{2}{*}{\multicolumn{1}{c|}{ Animal species }} & \multicolumn{2}{c|}{ Sex } & \multicolumn{2}{c|}{ Age groups (Y) } \\
\cline { 2 - 5 } & Females & Males & $<\mathbf{2}$ & $\mathbf{2}$ - > 2 \\
\hline Cattle & 16 & 9 & 17 & 8 \\
\hline Buffaloes & 18 & 7 & 15 & 10 \\
\hline Sheep & 13 & 12 & 11 & 14 \\
\hline Horses & 14 & 11 & 11 & 14 \\
\hline Total & 61 & 39 & 54 & 64 \\
\hline
\end{tabular}

The presented data in Table (2) showed that the overall prevalence of mites in investigated animal species was $46 \%$ that was higher that recorded by George et al., (1992) who found that from a total of 794 suspected cases, $247(31.1 \%)$ were positive for mange mites and it agreed with Mitra et al., (1993) recorded an outbreak of Sarcoptes scabiei in animals in West Bengal State, India. In addition, the statistical analysis showed significant association (11.11, $\mathrm{P}<0.05)$ between prevalence of mites and the investigated animal species in the current study. The highest prevalence was observed in sheep $(72 \%)$ followed by cattle $(48 \%)$ then buffaloes $(36 \%)$

\section{Examination of samples:}

The scraped material is placed in a drop of mineral oil on a slide and the entire area under the glass cover is scanned under low power magnification. Few drops of $10 \%$ potassium hydroxide solution may be added to clear debris and allow better visualization (Hay et al., 2006).

\section{Statistical analysis:}

Statistical analysis was made using $\mathrm{Chi}^{2}$-test for examining the significance of the prevalence of mites among the examined samples according to (SAS, 2014). and finally horses (28\%). The obtained result of sheep prevalence was extremely higher than those recorded by Salifou et al., (2013) who examined 574 West African dwarf sheep and found that the prevalence of scabies was $4.2 \%$ and they decided that close contact between human and their animals was a determining factor in the interspecies communicability of sarcoptic mange. The obtained result of cattle prevalence was lower than Warnick et al., (2002) who found that of the 1,597 cattle examined, 1,397 $(87.5 \%)$ had lesions consistent with mange, while the obtained result of prevalence of mange in buffaloes was higher than El-Khodery et al., (2009) 
who examined clinically and parasitologically a total of 318 buffalo in 77 small scale herds suspected to have mange mites and found that 53 (16.66\%) buffalo in 25 herds were recorded to be infected. on the other hand it was lower than Yassin, (2011) who found that 466 out of 560 examined buffaloes were infected with mange at the rate of $83.2 \%$. The obtained result of horse prevalence was higher than that recorded by Osman et al. (2006) who detected mites in 20 out of 117 (17.09\%) examined drafting horses At Kafr ElSheikh province.

Table (2): Prevalence of mange in different animal species

\begin{tabular}{|c|c|c|c|}
\hline $\begin{array}{c}\text { Species } \\
(n=25 / \text { each })\end{array}$ & No. of positive samples & $\%$ & $\begin{array}{l}\text { Statistical } \\
\text { analysis }\end{array}$ \\
\hline Cattle & 12 & 48 & \multirow{5}{*}{$\begin{array}{c}11.11 \\
P<0.05\end{array}$} \\
\hline Buffaloes & 9 & 36 & \\
\hline Sheep & 18 & 72 & \\
\hline Horses & 7 & 28 & \\
\hline Total & 46 & 46 & \\
\hline
\end{tabular}

The effect of sex on the prevalence of mites in different investigated species was illustrated in Table (3). The statistical analysis of the obtained results showed nonsignificant association between the prevalence of mange in females and males so sex has no effect on the prevalence of mange in the examined animal species in the current study although the prevalence of mange was higher in females than in males in examined samples of cattle (50 and $44.44 \%$, respectively), buffaloes (38.89 and $28.57 \%$, respectively), sheep (84.62 and $58.33 \%$, respectively) and horses (28.57 and 27.27\%, respectively). The obtained results was compatible with Osman et al. (2006) who found that sex of the examined horses had no clear influence on the prevalence of the infection. On the other hand, they disagreed with Yassin (2011) examined 560 buffaloes and found that the infection on females was $90.4 \%$, while on males was $80.8 \%$.

Table (3): Prevalence of mange in relation to sex of animals

\begin{tabular}{|l|c|c|c|c|c|c|}
\hline \multirow{2}{*}{ Species } & \multicolumn{3}{|c|}{ Females } & \multicolumn{3}{c|}{ Males } \\
\cline { 2 - 7 } & No. & Positive & $\%$ & No & Positive & $\%$ \\
\hline Cattle & 16 & 8 & 50.00 & 9 & 4 & 44.44 \\
\hline Buffaloes & 18 & 7 & 38.89 & 7 & 2 & 28.57 \\
\hline Sheep & 13 & 11 & 84.62 & 12 & 7 & 58.33 \\
\hline Horses & 14 & 4 & 28.57 & 11 & 3 & 27.27 \\
\hline & \multicolumn{7}{|c|}{$9.67 \mathrm{P}<0.05$} & \multicolumn{3}{c|}{2.83 NS } \\
\hline Total & 61 & 30 & 49.18 & 39 & 16 & 41.02 \\
\hline & \multicolumn{7}{|c|}{0.63 NS } \\
\hline
\end{tabular}


Distribution of mites' infestation with regard to age was recorded in Table (4) and revealed that the statistical analysis showed significant association between the prevalence of mange in different age groups under investigation. The prevalence of mange was higher in the age group ( $\geq$ 2 years) than in the age group $(<2$ years) in cattle (87.50 and $29.41 \%$, respectively), buffaloes (50 and
$26.67 \%$, respectively) and horses (28.57 and $27.27 \%$, respectively). On contrary, it was higher in the age group ( $<2$ years) than in the age group $(\geq 2$ years) in sheep (72.72 and $71.43 \%$, respectively). The obtained results was compatible with Osman et al. (2006) who found that the age of the examined horses had no clear influence on the prevalence of the infection.

Table (4): Prevalence of mange in animal species in relation to age groups

\begin{tabular}{|l|c|c|c|c|c|c|}
\hline \multirow{2}{*}{ Species } & \multicolumn{3}{|c|}{$<2$ years } & \multicolumn{3}{c|}{$\geq 2$ years } \\
\cline { 2 - 7 } & No. & Positive & $\%$ & No & Positive & $\%$ \\
\hline Cattle & 17 & 5 & 29.41 & 8 & 7 & 87.50 \\
\hline Buffaloes & 15 & 4 & 26.67 & 10 & 5 & 50.00 \\
\hline Sheep & 11 & 8 & 72.72 & 14 & 10 & 71.43 \\
\hline Horses & 11 & 3 & 27.27 & 14 & 4 & 28.57 \\
\hline \multicolumn{3}{|c|}{$7.57 \mathrm{NS}$} \\
\hline Total & 54 & 20 & 37.04 & 46 & 26 & 56.52 \\
\hline & \multicolumn{7}{|c|}{$3.79 \mathrm{NS}$} \\
\hline
\end{tabular}

Table (5) showed the frequency of isolated mite type/species and the investigated animal species. The statistical analysis showed nonsignificant association between frequencies of isolation of mites from investigated animal species. It was found that the overall prevalence of Sarcoptes spp. and Psoroptes spp. was 56.52 and $43.48 \%$, respectively. Concerning cattle, it was found that the prevalence of Sarcoptes spp. (58.33\%) was higher than Psoroptes spp. (41.67\%). In buffaloes, the prevalence of Sarcoptes spp. (66.67\%) was higher than Psoroptes spp. (33.33\%). Moreover, the prevalence of Sarcoptes spp. $(71.43 \%)$ was higher than Psoroptes spp. (28.57\%) in horses. On contrary, it was found that the prevalence of Psoroptes spp. (61.11\%) was higher than Sarcoptes spp. (38.89
$\%$ in the examined samples of sheep. These results were in harmony with that obtained by Gabaj et al. (1992) who found that the commonest parasites on cattle were Psoroptes and Chorioptes, on sheep were Sarcoptes and Psoroptes, and on horses were Psoroptes or Chorioptes, Warnick et al. (2002) who found that skin scrapings of cattle revealed Sarcoptes mites, El-Khodery et al. (2009) who found that $16.35 \%$ had psoroptic mites while only $0.31 \%$ had chorioptic mites. On contrary, it disagreed with George et al. (1992) who recorded that the most common mite species were Demodex folliculorum on cattle, Biu and Wakawa (2004) who conducted a prevalence study of chorioptic mange infection in 355 cattle in Nigeria and recorded a prevalence of $25.4 \%$. 
Table (5): Frequency of isolation of mites from investigated animal species

\begin{tabular}{|l|c|c|c|c|c|c|c|c|c|c|}
\hline \multirow{2}{*}{ Isolate } & \multicolumn{2}{|c|}{ Cattle } & \multicolumn{2}{c|}{ Buffaloes } & \multicolumn{2}{c|}{ Sheep } & \multicolumn{2}{c|}{ Horses } & \multicolumn{2}{c|}{ Total } \\
\cline { 2 - 11 } & No & $\%$ & No & $\%$ & No & $\%$ & No & $\%$ & No & $\%$ \\
\hline Sarcoptes spp. & 7 & 58.33 & 6 & 66.67 & 7 & 38.89 & 5 & 71.43 & 26 & 56.52 \\
\hline Psoroptes spp. & 5 & 41.67 & 3 & 33.33 & 11 & 61.11 & 2 & 28.57 & 20 & 43.48 \\
\hline & \multicolumn{2}{|c|}{$0.66 \mathrm{NS}$} & \multicolumn{2}{|c|}{$2.0 \mathrm{NS}$} & \multicolumn{2}{c}{$1.78 \mathrm{NS}$} & $2.57 \mathrm{NS}$ & \multicolumn{2}{c|}{$1.56 \mathrm{NS}$} \\
\hline
\end{tabular}

\begin{tabular}{|l|l|}
\hline & \\
\hline Photo (1): Mange like lesions in buffaloes & Photo (2): Mange like lesion in sheep \\
\hline & \\
\hline
\end{tabular}




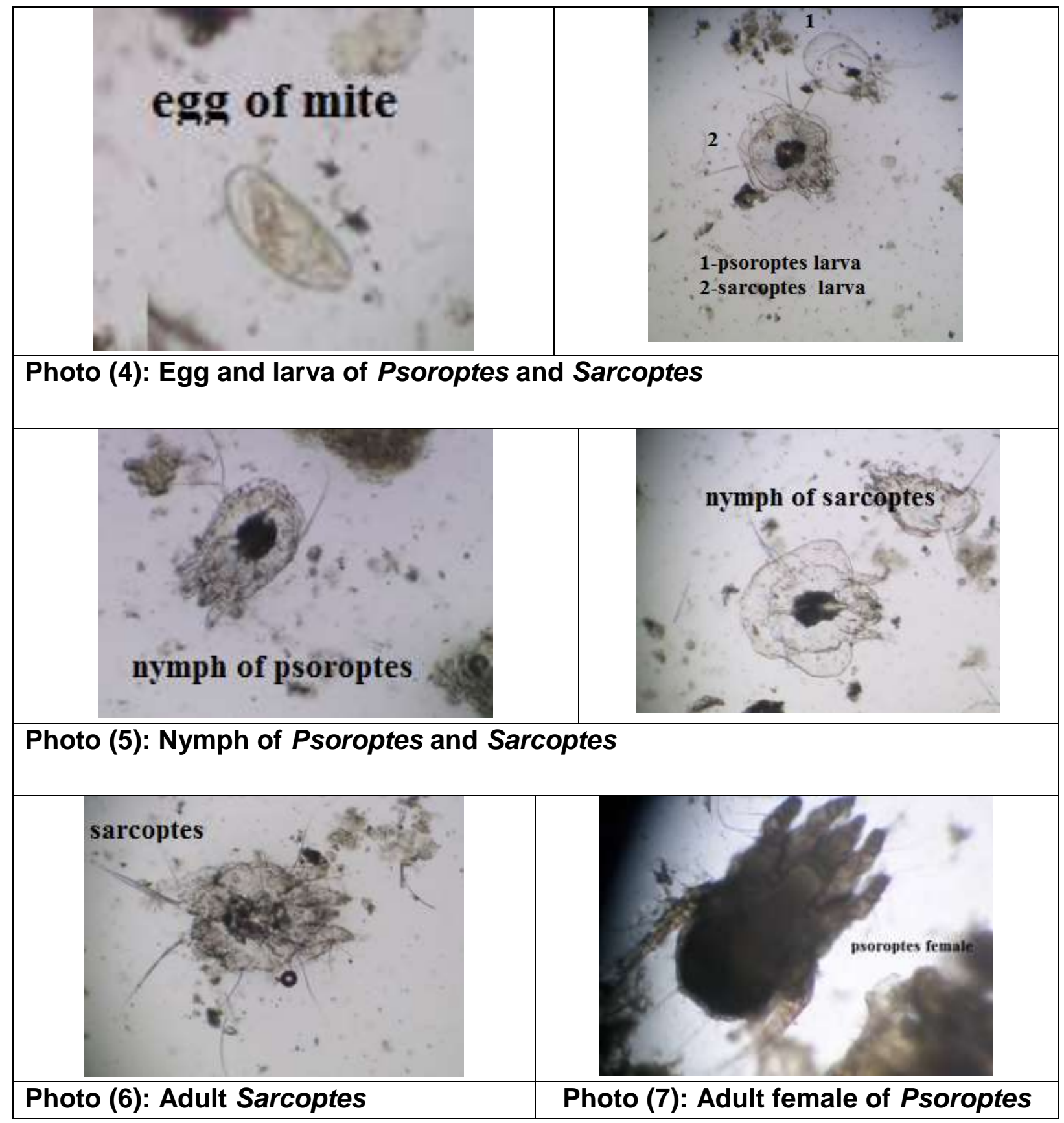

\section{CONCLUSION}

Based on the obtained results, it was clear that cattle, buffaloes, sheep and horses were considered to be potential reservoirs for scabies that might constitute a zoonotic risk for human contacts and further molecular epidemiological studies should be done to highlight the zoonotic importance of them. Although no human samples were examined in the current work, the zoonotic hazard must not be neglected and further future studies should be carried out to highlight the zoonotic importance of Psoroptes spp. and Sarcoptes spp.

\section{REFERENCES}

Alasaad S., Rossi L., Heukelbach J., Perez J. M., Hamarsheh O., et al. (2013): The neglected navigating web of the incomprehensibly emerging and 
re-emerging Sarcoptes mite. Infect.

Genet. Evol.; 17: 253-259

Amer, S., Abd El Wahab, T., El Naby Metwaly, A., Feng, Y. and Xiao, L. (2015): Morphologic and Genotypic Characterization of Psoroptes Mites from Water Buffaloes in Egypt. PLoS One. 30; 10(10): e0141554.

Biu, A. A and Wakawa M. M. (2004): Chorioptic mange infestation in cattle in Borno state, Nigeria. Pakistan Vet., J., 24(3): 155-156.

Blood, D.C., O.M. Rodstitts, and J.A. Henderson, (1990): Sarcoptic mange (Barn itch, red mange). In Veterinary Medicine: A text book of the diseases of cattle, pigs, sheep, goats and horses, 8th Ed. The Britain Bath Press, Avon, UK.

Burkhart, C.G., Burkhart, C.N., and Burkhart, K.M. (2000): An epidemiologic and therapeutic reassessment of scabies. Cutis; 65: 233-240

El-Khodery, S. A., Ishii, M., Osman, S.A. and Al-Gaabary, M.H. (2009): Comparative therapeutic effect of moxidectin, doramectin and ivermectin on Psoroptes mites infestation in buffalo (Bubalus bubalis). Trop. Anim. Health Prod.; 41(7):1505-1511.

Fuller, L.C. (2013): Epidemiology of scabies. J. Curr. Opin. Infect. Dis.; 26(2):123-6.

Gabaj, M.M., Beesley, W.N. and Awan, MA. (1992): A survey of mites on farm animals in Libya. Ann Trop Med Parasitol.; 86(5): 537-42.

George J.B., Otobo S., Ogunleye J. and Adediminiyi B. (1992): Louse and mite infestation in domestic animals in northern Nigeria. Trop. Anim. Health Prod.; 24(2):121-4.
Hay, R.J., Mahé, A., Estrada, R. (2006): Skin disease. In: DT Jamison, JG Breman, AR Measham, (Eds.) Disease control priorities in developing countries. World Bank and Oxford University Press Publications, New York; 707-722

Kenawi M., Morsy T., Abdalla K., Nasr M., Awadalla R. (1993): Clinical and parasitological aspects on human scabies in Qualyobia Governorate, Egypt. J. Egypt. Soc .Parasitol. 23: 247-253

Kollbrunner M., Luginbühl A. and Pfister K. (2010): Epidemiological aspects of Chorioptes-mange in dairy cows in Switzerland: a field study. Schweiz Arch Tierheilkd.; 152(5):231236.

Millar M., Milnes A., Wood K., Mitchell S. and Kendall B. (2011): Psoroptic mange in cattle confirmed in England. Veterinary Record; 168:334

Mitchell, E. S., Jones, J. R., Foster, A. P., Millar, M., Milnes, A. and Williams, J. (2012): Clinical features of psoroptic mange in cattle in England and Wales. Veterinary Record; 170:359

Mitra M., Mahanta S.K., Sen S., Ghosh C. and Hati A.K. (1993): Sarcoptes scabiei in animals spreading to man. Trop Geogr Med.; 45(3):142-143.

Nimmervoll H., Hoby S., Robert N., Lommano E., Welle M., et al. (2013): Pathology of sarcoptic mange in red foxes (Vulpes vulpes): macroscopic and histologic characterization of three disease stages. J. Wild Dis. 49: 91-102

Nofal A. (2009): Variable response of crusted scabies to oral ivermectin: report on eight Egyptian patients. J. Eur. Acad. Dermatol. Venereol. 23: 793-797 
Osman S.A., Hanafy A. and Amer S.E. (2006): Clinical and therapeutic studies on mange in horses. Vet Parasitol., 10; 141(1-2):191-195.

Pence, D. and Ueckermann, E. (2002): Sarcoptic mange in wildlife. Rev. Sci. Tech. 21: 385-398 Salifou S., Attindéhou S., Folakè C., Salifou A., and Pangui L. J. (2013): Prevalence and zoonotic aspects of small ruminant mange in the lateritic and waterlogged zones, southern Benin. Rev. Bras. Parasitol. Vet., Jaboticabal, 22 (2): 243-247.

Sarre C., De Bleecker K., Deprez P., Levecke B., Charlier J., Vercruysse J. and Claerebout E. (2012): Risk factors for Psoroptes ovis mange on Belgian Blue farms in Northern Belgium. Vet Parasitol., 23;190(12):216-221.

SAS, (2014): Statistical user's Guide. Statistical analysis system. Cary, NC. USA.

Tidman, A.S. and Tidman, M.J. (2013): Intense nocturnal itching should raise suspicion of scabies. Practitioner; 257(1761):23-7, 2.

Warnick, L.D., Ana Maciel, D. N., Guard, C.L. and Wade, S.E. (2002): Udder cleft dermatitis and sarcoptic mange in a dairy herd. J. Am. Vet. Med. Assoc. 21, (2): 273-276

Yassin M.K. (2011): Mange mites causing scabies in Egyptian buffaloes at Giza Governorate, Egypt. J. Egypt Soc. Parasitol.; 41(1): 55-64. 


\section{دراسة معدل انتشار طفيل الجرب في بعض الحيوانات المصابة في محافظة البحيرة}

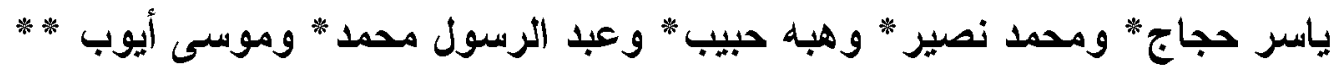

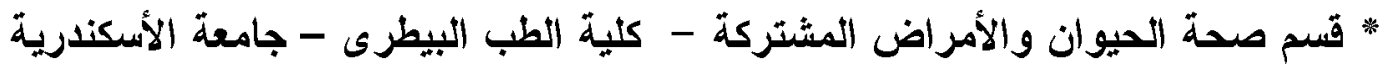
* ق قسم صحة الحيوان والأمراض المشتركة - كلية الطب البيطرى - جامعة دمنهور

تعثبر الأمراض الجلدية المشتركة من أكثر الأمراض النى ينعرض لها المخالطين لحيوانات

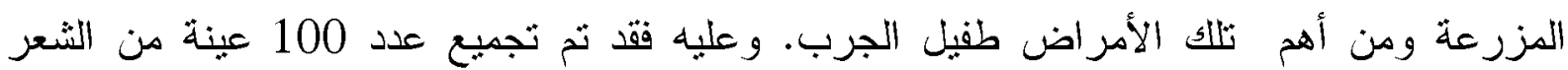

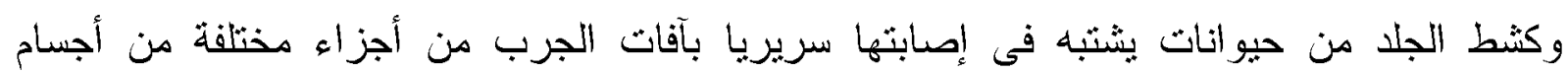
الحيو انات المثرددة على الوحدات البيطرية والعيادات الخاصة في مركز أبو المطامير بمحافظة البحيرة

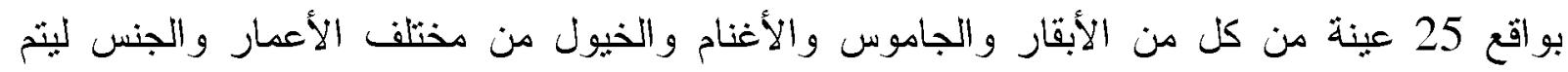

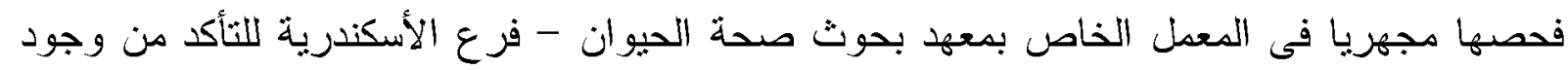

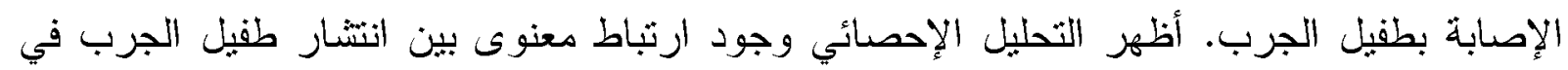
الحيو انات موضع الدراسة وقد لوحظ أن أعلى نسبة لانتشارطفيل الجرب كانت في الأغنام (72٪)

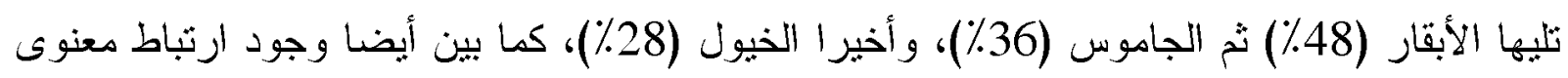

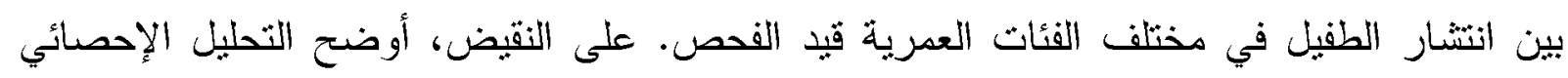

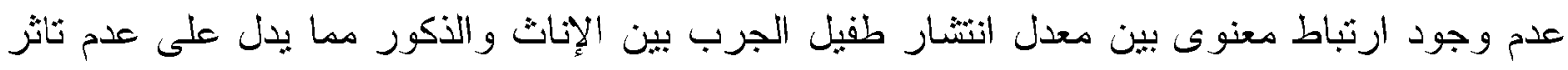

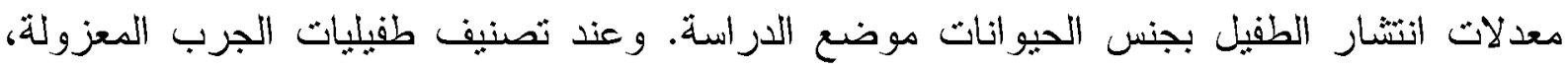
تيين أن معدل انتثار القارمة النيابة (Sarcoptes mange) و القارشة النيابة ( Psoroptes

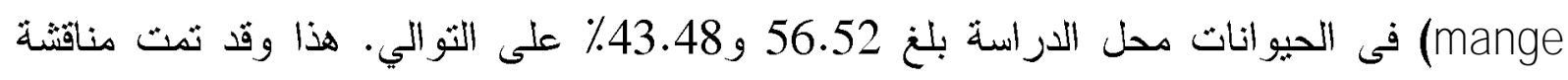

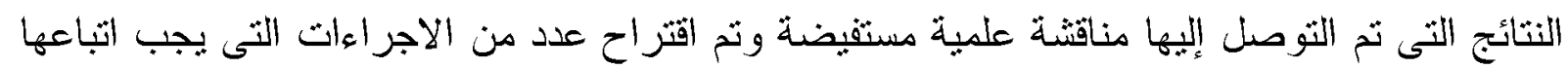

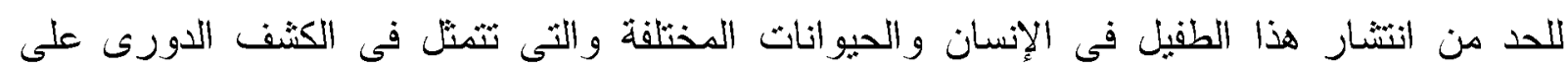

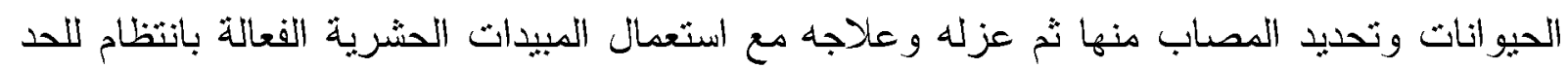

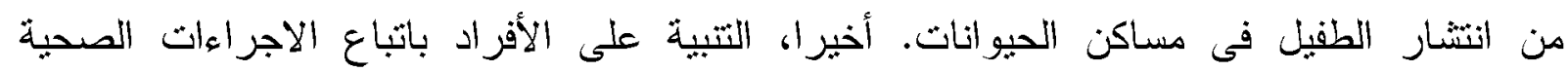

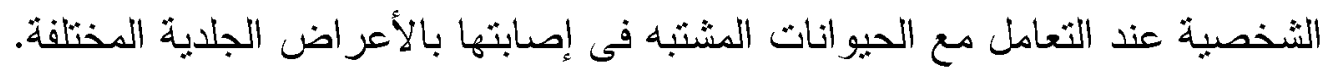

